\title{
Do large private protected areas contribute to sustainable development? A case study from the Huilo Huilo Biological Reserve in Neltume, Chile
}

\author{
Benedikt Hora
}

Keywords: private protected areas, sustainable tourism, Chilean Andes, economic transition

\section{Abstract}

This study explores the impacts perceived by the local population in Neltume, a small rural village in the mountains of southern Chile, after a private protected area, the Huilo Huilo Biological Reserve, was established. Since the 1990s, Neltume has experienced economic transition from the forestry sector to the development of special-interest tourism. This research aims to investigate how this transition affects the local population and tourism in the area. Methods used were secondary data review, participant observation, semi-structured interviews with key informants, and questionnaires with local householders, students and tourists. The results indicate that this kind of private protected area plays an important role in local development. However, such developments could present a risk in the future because they create a strong dependency for local inhabitants on just one economic activity.

\section{Profile}

Protected area

Huilo Huilo Biological

Reserve

Mountain range

Andes

Country

\section{Introduction}

Private actors have become increasingly prominent in conserving naturally valuable areas. Their numbers are rising thanks in particular to neoliberal tendencies in conservation which emphasize and strengthen the role of private individuals. This phenomenon can be observed worldwide, particularly in developing countries. Private initiatives can be linked to biodiversity conservation, biocarbon sequestration, biofuels, ecosystem services and ecotourism (Fairhead et al. 2012). Igoe \& Brockington (2007) argue that the neoliberalization of conservation involves the regulation of nature through commodification. Holmes (2012, 2014) points out three reasons for this new phenomenon. Firstly, the retreat of state bodies and an increase of NGOs who are running protected areas, formulating policies, and becoming more active in other environmental protective activities. Second, conservation is increasingly integrated in market mechanisms. In order to protect biodiversity, valuable land is sold, for example for bio-prospecting or ecotourism, or as payments for ecosystem services. Third, since the 1980 s and accelerating since the 2000s, leading NGOs have increased their cooperation with companies, copying their methods, for example in marketing, and showing their own activities in a good light.

In Latin America, private actors are the main drivers in transforming environmentally valuable land into protected areas (Büscher \& Whande 2007). This is facilitated by the new global policies dealing with climate change and environmental degradation. One example is the Regenwald der Österreicher environmental project in Costa Rica, in which an Austrian non-profit organization helped the Costa Rican government fi- nancially to implement a rainforest protection area where the forest was threatened by logging. Another example is the Mbaracayú Natural Forest Reserve in Paraguay, which aims to protect the Atlantic Forest, one of the five world biodiversity hotspots (Quintana \& Morse 2005). In Brazil, similar private initiatives have been developed. There, the small private reserves $(<50 \mathrm{ha})$ tend to be more successful in conservation and ecotourism (Pegas \& Castley 2014). Chile has 308 Private Protected Areas (PPAs), with an estimated area of 1651916 ha (Núñez et al. 2013). In Chile, Mapuche indigenous communities have implemented private protection initiatives on their territories (Meza 2009).

According to the IUCN guidelines, PPAs are defined as those "under individual, cooperative, NGO or corporate control and/or ownership, and managed under notfor-profit or for-profit schemes [...] [where] the authority for managing the protected land and resources rests with the landowners, who determine the conservation objective, develop and enforce management plans and remain in charge of decisions, subject to applicable legislation" (Dudley 2008, 26). Newly established areas are often considered problematic, as benefits from the areas' resources are seized by outsiders, causing exclusion and harm to local people and possibly leading to displacement and impoverishment. For example, evidence from the ecotourism project in the Tayrona National Park in Colombia (90\% of which remains in private hands) shows that ancestral inhabitants were displaced. In 2010, fishermen who were living beside the beach in the park were evicted. Most of them left for the nearby city of Santa Marta (Ojeda 2012). In the coastal areas of Tanzania, wildlife conservation has led to an end of former activities (e.g. smallscale fishing) and capital accumulation by a number of powerful actors (revenue-seeking state of- 


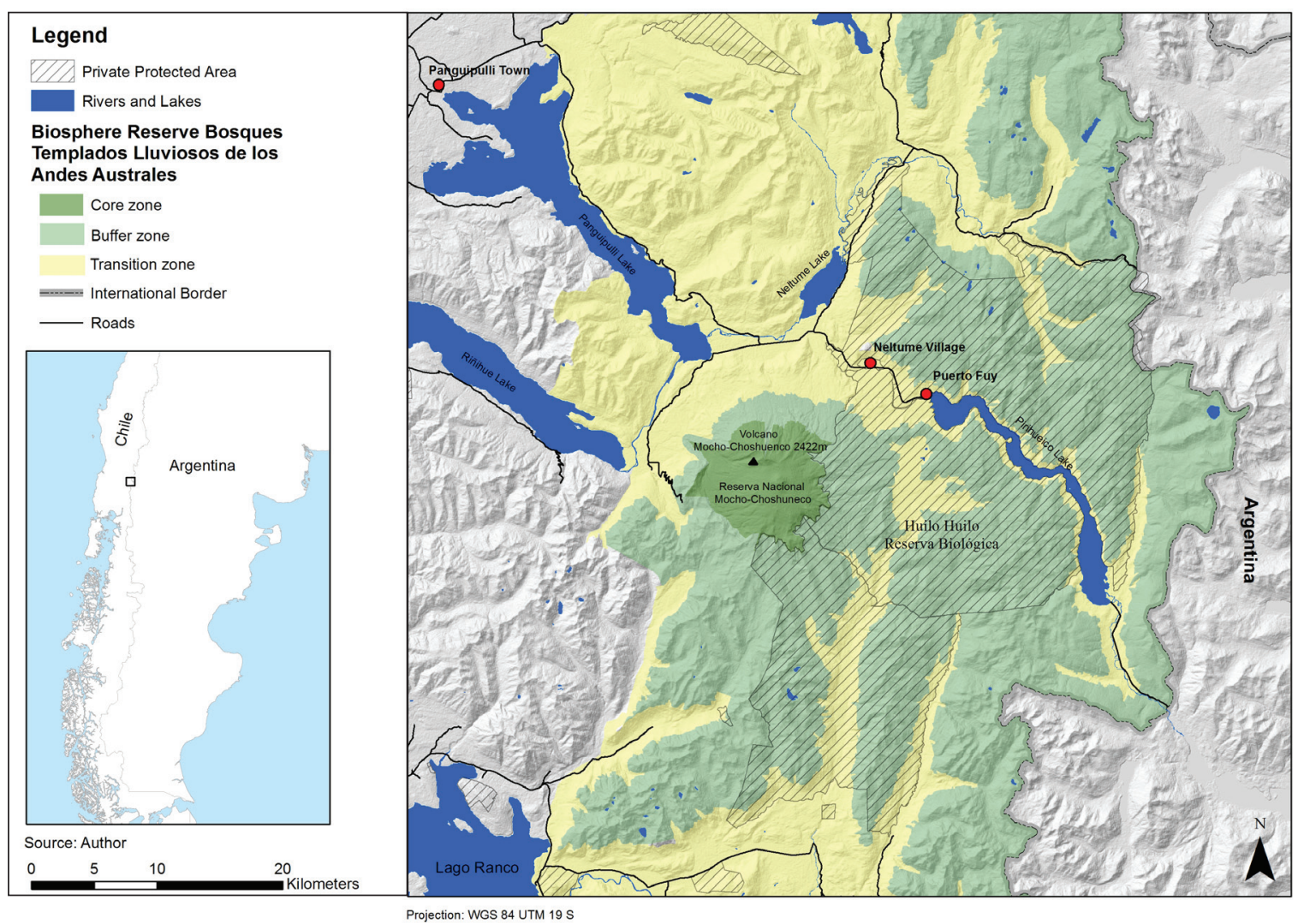

Figure 1 - Study area.

ficials, international conservation organizations, tourist companies, the State Treasury) (Benjaminsen \& Bryceson 2012). However, harm to the local people can be mitigated if the protection process is carried out in a participatory manner. Although establishing PPAs can result in conflicts, they make a significant contribution to biological conservation in some areas (Holmes 2013), and analysing PPAs is important because they are relatively rarely studied. It is also relevant to explore how and why this trend has emerged and the impacts that PPAs have on both people and nature (Holmes 2015).

Chile presents a good example of neoliberal change in Latin America, which was introduced shortly after the establishment of the military regime (1973). From then on, private actors took over public tasks. Private actors also became more active in conservation (Sepúlveda 1997; Corcuera 2000; Tecklin \& Sepúlveda 2014). The first PPAs were established in Chile at the end of the 1980s (Parque Oncol 1989; Santuario El Cañi 1990; Parque Pumalín 1991) (Sepúlveda \& García 1997). Holmes (2013) mentions four factors that have facilitated their implementation in Chile:

- The strong property rights;

- market-orientated solutions propagated by the military regimen;

- the possibility of running a PPA profitably, especially through speculation;

- a sufficient number of wealthy Chileans who are interested in owning a PPA.
Public protected areas cover $19.2 \%$ of Chile's territory, comprising 36 National Parks, 49 National Reserves and 15 Natural Monuments, and covering 14500000 million ha (Sierralta et al. 2011). Most of the protected areas are concentrated in the far south, in the Patagonian fjords region, and the extreme north of the country, where conflicts in land use are rare.

Chile has 308 PPAs, with an estimated area of 1651916 ha (Núñez et al. 2013), or 2.12\% of Chile’s territory. However, they tend to be in areas with higher protection value and threatened biomes (Pliscoff \& Fuentes-Castillo 2001), mainly in areas of the Chilean temperate forests, which are classified as biological hotspots (Echeverría et al. 2006). 34\% of the plants in these forests are endemic (Armesto et al. 1996). Important endemic trees located in the area are from the Nothofagus (southern beeches) family or the Fit:roya cypressoides (Alerce), among many others.

Many areas of native forest in southern Chile were converted in the $20^{\text {th }}$ century to forest plantations, where the Pinus radiata imported from California and Eucalyptus globulus are found in monocultures for cellulose extraction and wood chip production (Oyarzún \& Huber 1999). The Decree Law 701 of 1974 aimed to convert the forestry industry into a largely privately owned, exporting business. This included selling the country's forests at artificially low prices to private industry, direct subsidies for plantation $(75 \%$ of the cost), and tax exemptions (Wilson et al. 2005). This ongoing process has led to decreasing native forests. 
Plantations are found particularly in the regions of Bio-Bio, la Araucanía, Los Ríos and Los Lagos. This destruction of native forest also enhanced the interest of implementing PPAs.

In this process towards PPAs, the Reserva Biológica Huilo Huilo can be seen as an emblematic example. The forestry industry was in a crisis and the native forests in the area were becoming increasingly decimated. With the establishment of the reserve and the conversion to tourism, a new economic opportunity developed not only for the owners of the reserve but also for the local community. The public sector has also helped the region to become a tourist destination, through the creation of the Destino Turístico Siete Lagos within the strategic regional development plan of the Los Ríos region. Serenari et al. (2015) have already carried out an investigation of the community living close to the Reserva Biológica Huilo Huilo using a cultural consensus survey. The study showed that the community had divided opinions about the private reserve. One group missed jobs in the forestry industry; the other was happy with the new opportunities in tourism.

In this context, the present article aims to give an initial picture of the perceived impacts that the protected area has in a small rural village in southern Chile (Neltume), and of the inhabitants' perception of the local development. Focus groups were adult home-owners and students finishing high school. Visiting tourists were also asked for their opinions of this kind of conservation initiative. The main research questions were: How is the implementation of a PPA affecting those who live nearby socio-economically and socio-culturally? How do opinions differ between adults and young students? How is the project perceived by tourists? And finally, how is the implementation of the PPA shaping the regional development of Neltume and its surroundings?

\section{Study area}

The Reserva Biológica Huilo Huilo comprises around 100000 ha in the municipalities of Panguipulli and Futrono, in the Los Ríos region in Chile. It is located in the main Andean range close to the Argentinean border. The rural village studied, Neltume, which is surrounded by the Reserva, has approximately 3000 inhabitants (Zumelzu 2014).

The Reserva Biologica Huilo Huilo (Figure 1) is located within the Reserva de la Biósfera de los Bosques Templados, established by UNESCO in 2007. This biosphere reserve comprises 2296795 ha in which many other national parks are located (Pino et al. 2014). Most of the Reserva Biologica Huilo Huilo is located in the buffer zone of the Biosphere reserve, where limited human activity is permitted, and a transition zone where greater activity is allowed. The core zone with strict protection is located outside the reserve, within the Reserva Nacional Mocho-Choshuenco, on the slopes of the Mocho-Choshuenco volcano. On the Argentinian side, the Biosphere reserve borders on the Reserva de la Biósfera Andino Nordpatagónica.

This region of southern Chile was originally inhabited by Mapuche communities, an indigenous group who have their main living sites in the la Frontera area. The first non-indigenous residents came to the area in 1885. Then a mission from the Order of Friars Minor Capuchin arrived and established schools and churches (Kohut 2006). Neltume, which is situated further into the mountains, became colonized at the beginning of the $20^{\text {th }}$ century through a boom in the wood industry in Chile at the time. In 1947, Panguipulli became an official municipality (Rivas 2006).

During the first decades of the $20^{\text {th }}$ century, other colonists came, and extracting the native forest became a major economic activity in the area. The fundos (country estates) were organized privately by large land owners. In 1971, under Allende, the socialist government expropriated all the former owners in the area. They created a large-scale state-owned company which managed 360000 ha of land in the Cordillera of Panguipulli, Neltume, Liquiñe and Chihuío - the Complejo Forestal y Maderero Panguipulli. The productive centre of the Complejo was Neltume, where the sawmill and dryer were located. From there, the processed wood was transported via Choshuenco and Panguipulli to the markets. In total 3500 people were employed in the Company in the 1970s (CODEPU 1990). During the military regime, the company was run by the CONAF (Corporación Nacional Forestal). During the last phase of the military regime, the state owned properties; between 1987 and 1990, large amounts of the land were sold at cheap prices to Chilean businessmen (CODEPU 1990).

The Petermann family, who now own the Reserva Biológica Huilo Huilo, also bought shares in the complex. During the mid-1990s, when the forest industry was in crisis, Petermann sold off some land to investors, to be used as pleasure lots. Finally, in the year 2000, the Reserva Biológica Huilo Huilo was created, with an area of 60000 ha (Román \& Nahuelhual 2009). In recent years it has been extended to 100000 ha. Within the reserve, tourism projects were very soon started (Huilo Huilo Tourism Development, Huilo Huilo Foundation), and most recently the Real Estate Huilo Huilo was created. All these initiatives tended to present an idyllic, natural, wild image of the area.

In first decade of the $21^{\text {st }}$ century, the newly established tourist area started to attract foreigners and local Chileans alike. In recent years, access to the area has been improved by new paved roads along the north shores of Panguipulli lake, thus increasing the numbers of tourists.

\section{Methods}

Data used in this study was obtained during two periods of fieldwork: (1) between January and August 2015, and (2) in February and March 2016. A mixed 
methodology was used, consisting of secondary data review (including various government reports and $\mathrm{Hu}-$ ilo Huilo's visitors statistics provided by the Foundation), participant observation (informal conversations with local actors and participation in local activities), and 14 semi-structured interviews with key informants (Table 1).

The interviews were recorded and transcribed, and the contents were subsequently analysed using a codification method in which themes, words, phrases and interpretations are flagged within and across the transcripts (Gomez \& Jones 2010).

In order to garner local opinion about the socioeconomic and cultural changes driven by the implementation of this PPA, a survey with local people $(n=63)$ living in the nearby village of Neltume was carried out. More than 60 households were selected randomly and canvassed using a questionnaire. A sec- ond survey with students of Nelturne $(n=27)$ and young people, asking for their perceptions of the future development of the village, was conducted in the rural school. The intention was to have two local focus groups whose opinions would probably differ. Finally, in order to investigate the opinions and perceptions of visitors to Huilo Huilo $(n=138)$, tourists were asked for their opinions about the PPA. Table 2 summarizes the questions for each group.

All the information collected was triangulated, a technique which, according to Olsen (2004), allows the mixing of data or methods so that diverse viewpoints or standpoints cast light upon a topic. This method was used in order to validate the results of the study. The combination of the expert interviews, the different surveys and literature review allows the in-depth analysis of the perceived impacts of the PPA in the local development of Neltume.

Table 1 - Key informants interviewed.

\begin{tabular}{|c|c|c|}
\hline & Actor & Responsible for \\
\hline \multirow[t]{4}{*}{ Private sector } & Member of the landowner's family & Administration of the Reserva Biológica Huilo Huilo \\
\hline & Executive from the forestry sector & Forestry management plan of the Huilo Huilo project \\
\hline & Head of the Fundación Huilo Huilo & $\begin{array}{l}\text { Various social, environmental and research projects within the Fun- } \\
\text { dación Huilo Huilo }\end{array}$ \\
\hline & Huilo Huilo journalist & Public relations of the Reserva Biológica Huilo Huilo \\
\hline \multirow{3}{*}{$\begin{array}{l}\text { Governmental } \\
\text { offices }\end{array}$} & Head of the Mocho Choshuenco National Reserve & Administration of the Reserva Nacional Mocho Choshuenco \\
\hline & $\begin{array}{l}\text { Head of the Regional Office of Protected Areas } \\
\text { (CONAF) }\end{array}$ & Administration of the PPAs in the Los Ríos Region \\
\hline & Head of CONAF - Panguipulli & Administration of the PPAs in the Panguipulli section \\
\hline \multirow[t]{2}{*}{ NGOs } & Head of Nature Conservancy, Valdivia & Administration of the PPA Reserva Costera Valdiviana \\
\hline & $\begin{array}{l}\text { Staff member of the World Wildlife Foundation, } \\
\text { Valdivia }\end{array}$ & Working with the World Wildlife Foundation in Valdivia \\
\hline \multirow{4}{*}{$\begin{array}{l}\text { Local } \\
\text { stakeholders }\end{array}$} & Valdivian man working in the forestry business & Good knowledge of the forestry industry in the Los Ríos Region \\
\hline & Owner of a tourism agency in Neltume & $\begin{array}{l}\text { Running an ecotourism agency focused on special-interest tourism in } \\
\text { Neltume }\end{array}$ \\
\hline & Small tourism entrepreneur in Neltume & Running a hostel in Neltume \\
\hline & $\begin{array}{l}\text { Head of a civil organization (Frente ambientalista } \\
\text { de Panguipulli) }\end{array}$ & Coordinating various social and environmental groups in the region \\
\hline Academia & $\begin{array}{l}\text { Professor working on environmental conservation } \\
\text { from the Universidad Austral de Chile }\end{array}$ & $\begin{array}{l}\text { Experience in varoius environmental conservation projects in the } \\
\text { region and Chile }\end{array}$ \\
\hline
\end{tabular}

Table 2 - Summary of questions per group.

\begin{tabular}{|c|c|c|}
\hline Questions for local people & Questions for students & Questions for visitors \\
\hline $\begin{array}{l}\text { Household characteristics } \\
\text { Number of family members } \\
\text { How long resident in Neltume } \\
\text { Age and sex } \\
\text { Educational level } \\
\text { Current job/occupation }\end{array}$ & $\begin{array}{l}\text { Household characteristics } \\
\text { Number of family members } \\
\text { How long resident in Neltume } \\
\text { Age and sex } \\
\text { Educational level } \\
\text { Parents' current job/ occupation }\end{array}$ & $\begin{array}{l}\text { Basic biographical information } \\
\text { Place of residence Town / City/Country } \\
\text { Age and sex } \\
\text { Educational level } \\
\text { Current job }\end{array}$ \\
\hline $\begin{array}{l}\text { Are you working, or is someone in your } \\
\text { family working on the Huilo Huilo Project? } \\
\text { Where? }\end{array}$ & $\begin{array}{l}\text { What do you want to do after finishing school } \\
\text { (study at university, study for a technical } \\
\text { career, work)? }\end{array}$ & \multirow{5}{*}{$\begin{array}{l}\text { Basic information about your stay } \\
\text { How are you travelling? } \\
\text { Where are you staying? } \\
\text { How many days are you staying in the area } \\
\text { (Panguipulli municipality)? } \\
\text { How much will you spend (approx.) during } \\
\text { your stay? (US\$ or CLP) } \\
\text { What means of transport do you use? } \\
\text { In what outdoor activities do you participate } \\
\text { here in the Reserva Biológica Huilo Huilo? } \\
\text { Have you visited the Reserva Nacional Mo- } \\
\text { cho- Choshuenco? }\end{array}$} \\
\hline $\begin{array}{l}\text { Do you believe that the socio-economic situ- } \\
\text { ation has improved in recent years? Why? }\end{array}$ & $\begin{array}{l}\text { Would you like to work on the Huilo Huilo } \\
\text { project in the future? Why? }\end{array}$ & \\
\hline \multirow{2}{*}{$\begin{array}{l}\text { Do you think that Huilo Huilo is a support for } \\
\text { the community of Neltume? Why? }\end{array}$} & Where do you want to live in the future? & \\
\hline & $\begin{array}{l}\text { Do you think that Huilo Huilo is a support for } \\
\text { the community of Neltume? Why? }\end{array}$ & \\
\hline $\begin{array}{l}\text { Do you think that Huilo Huilo respects } \\
\text { labour rights of their workers? Why? }\end{array}$ & $\begin{array}{l}\text { Are you working, or is someone in your } \\
\text { family working on the Huilo Huilo Project? } \\
\text { Where? }\end{array}$ & \\
\hline $\begin{array}{l}\text { Are you satisfied with the activities developed } \\
\text { by the Fundacion Huilo Huilo in Neltume? }\end{array}$ & $\begin{array}{l}\text { Do you take part in the activities developed } \\
\text { by the Fundacíon Huilo Huilo in Neltume? } \\
\text { Which ones? }\end{array}$ & \multirow{2}{*}{$\begin{array}{l}\text { Opinions about your stay } \\
\text { Do you like the conservation concept of the } \\
\text { Reserva Biológica Huilo Huilo? } \\
\text { Do you find the entrance fees and activi- } \\
\text { ties within the Biological Reserve cheap or } \\
\text { expensive? }\end{array}$} \\
\hline Your opinion of the Huilo Huilo Project & $\begin{array}{l}\text { How do you see your future? And your job? } \\
\text { Write a few words. }\end{array}$ & \\
\hline
\end{tabular}




\section{Results}

Socio-demographic profile of the local inhabitants of Neltume

The average age of the inhabitants questioned was 45. The average time the people had lived in Neltume was 30 years. 21 were male and 42 were female. The households had an average 3.6 members. $31.6 \%$ were between 0 and 18 years of age; 59.4\% were aged 18 to 65 , and $9 \%$ were over 65 . People were asked about the occupation of the other members of their households. 32 were working in the tourism sector, 20 in the forestry sector, 5 in other businesses, and 6 were retired. The majority of the inhabitants work in tourism, but a significant minority are still active in forestry, while others worked independently, for example in their own small shops.

Where educational level was concerned, 33 had basic education ( 8 years of formal education in Chile), 25 had a medium level of education (12 years of formal Chilean education), and 5 had a university degree.

\section{Current economic activities}

A wide variety of special-interest tourist activities and sightseeing opportunities exist in Neltume (Figure 2). Outdoor activities possible in the area include rafting in the Fuy river, kayaking on Pirihueico lake, trekking, mountaineering, skiing (Huilo Huilo is the only ski resort in South America where you can go skiing all year round), mountain biking, horse riding and fly fishing. The most important cultural attraction is the museum, the Centro Cultural Museo y Memoria de Neltume, which presents the history of the Mapuche culture, and the economic changes in the area in recent decades. There is another museum, the Museo de los Volcanes, within the Huilo Huilo territory. This complex also includes its own brewery, the Petermann Artisanal Brewery, and a restaurant.

The Fundación Huilo Huilo also develops conservation projects, which attract scientific tourism to the area, and organize various festivals, such as the spring festival or the Festival de Artes in Neltume (Figure 3). These initiatives bring the community together and give the inhabitants the chance to participate in workshops to learn new skills (mosaics, crafts and natural cosmetics).

With regard to the tourism infrastructure in the village, accommodation has increased from just one hostel in 2005 to more than 15 cabins, 5 hostels and bed $\&$ breakfasts, 4 camp sites, 6 lodges and 2 hotels in 2016. Services like small supermarkets, bakeries, coffee shops, restaurants, internet facilities and craft shops are also to be found, all developed by local families.

The Reserva Biológica Huilo Huilo has won various awards for sustainable tourism: as best destination for Conservación de la Vida Silvestre y su Hábitat, and the Virgin Holidays Responsible Tourism Award 2012. It also won the Ecotrophea awarded by the German Travel
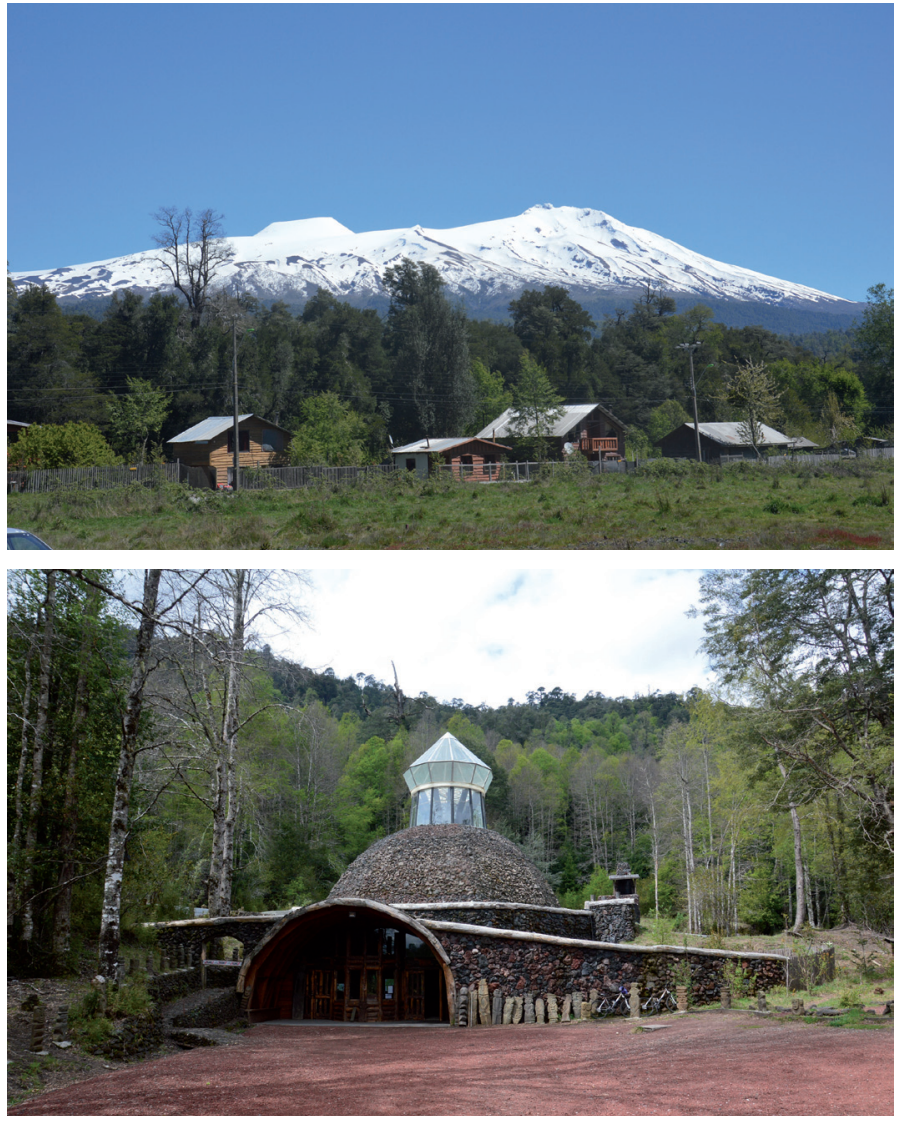

Figure 2 - (top) Neltume and the Mocho Choshuenco; (bottom) Museo de los Volcanes (C) B. Hora
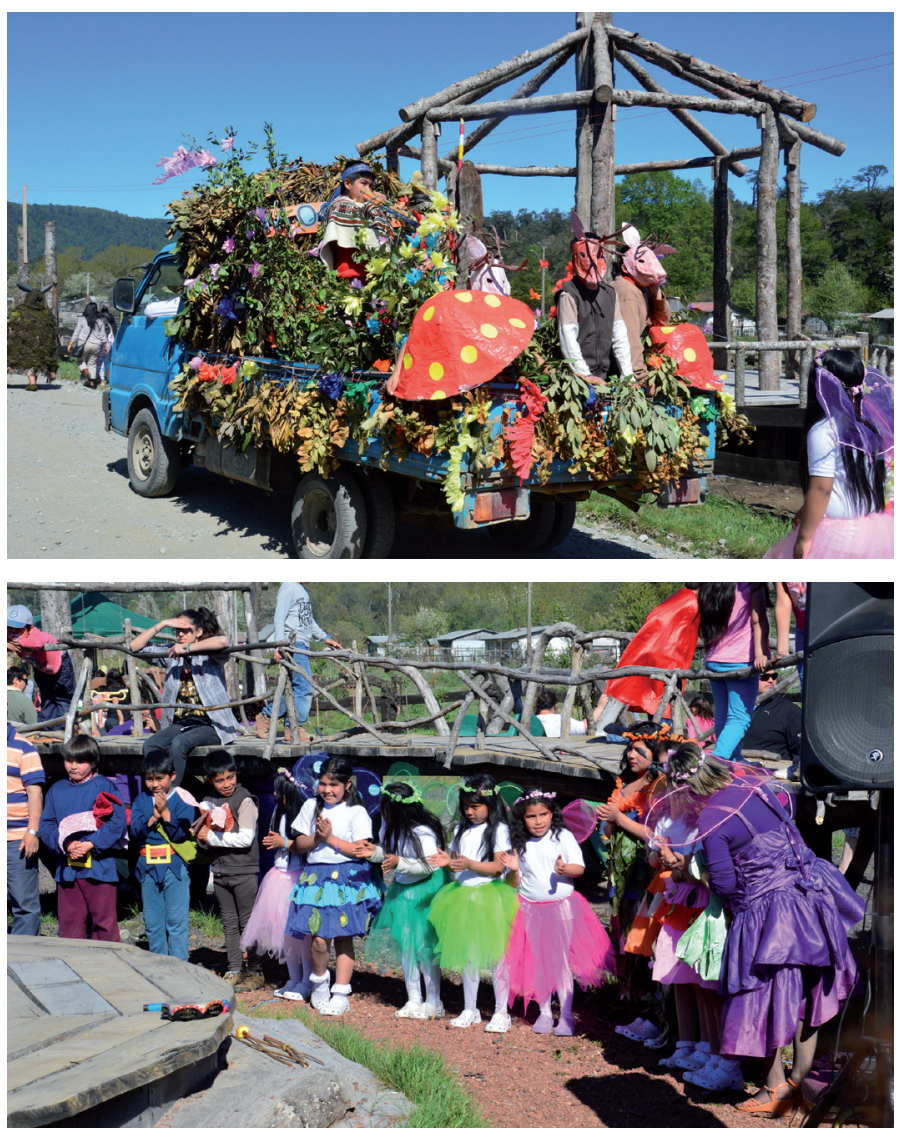

Figure 3 - Activities during the spring festival in Neltume, 2015. C B. Hora 
Agency (DRV) in 2012. In 2015, it won the World Legacy Award in the category Conservation of the real world organized by National Geographic. At national level, in 2011 Huilo Huilo won FEDETUR's (Federación de Turismo) recognition as the most sustainable tourist destination in the country.

Socio-economic changes perceived by the inhabitants of Neltume

Of the 63 inhabitants questioned, 12 (19\%) answered that they had definitely experienced a socio-economic improvement in recent years (Figure 4). 32 (51\%) said that they had experienced moderate economic improvement. In answer to the question about whether the Huilo Huilo project was helping support the local community (Figure 5), 25 (40\%) stated that it definitely was; $24(38 \%)$ thought that the project had brought some moderate improvement. The peak-season income isn't enough alone to live off for a whole year.

The households of Neltume who were less satisfied with their economic situation were those who were generating their income predominantly from forestry, which is in decline because the Reserva Biologica Huilo Huilo focuses on conservation. This new model of development based on tourism was a big change for the older people, because it implies a new relationship with nature. One interviewee (male, over 70) said: „We had worked with wood for our entire life ... For us, if we did not cut down a tree, there was no bread... When Mr. Petermann came and bought here in Huilo Huilo, we thought that we would be unemployed, we didn't understand what tourism was." In the household survey, people who declared that they were completely satisfied or more or less satisfied with their economic situation had a total of 20 out of 22 family members working in the tourism sector. The people still working in forestry saw their own economic situation as less prosperous, but they didn't want to be involved in tourism. However, the picture is not black and white because some of the households that included forestry workers also had family members working in the tourism sector. In total, there are only 85 inhabitants of Neltume working directly for the Forestal Neltume Carranco forestry plant.

Although the new work opportunities related to tourism are welcome, the inhabitants see problems regarding how this business currently functions. Firstly, people see a strong dependency on this seasonal activity, whose duration is really short, because in Chile winter tourism is not a massive phenomenon. Secondly, most of the people do not have start-up capital to set up their own businesses (mostly cabins, which are the preferred kind of undertaking), and they complain about the lack of government support to invest in the tourism sector. Thirdly, many of those interviewed see the implementation of the Neltume Hydroelectric Plant by the Spanish company Endesa as a serious risk for the environment and subsequently for tourist activities. The water required to operate the hydroelectric station will be carried from Lake Pirihueico

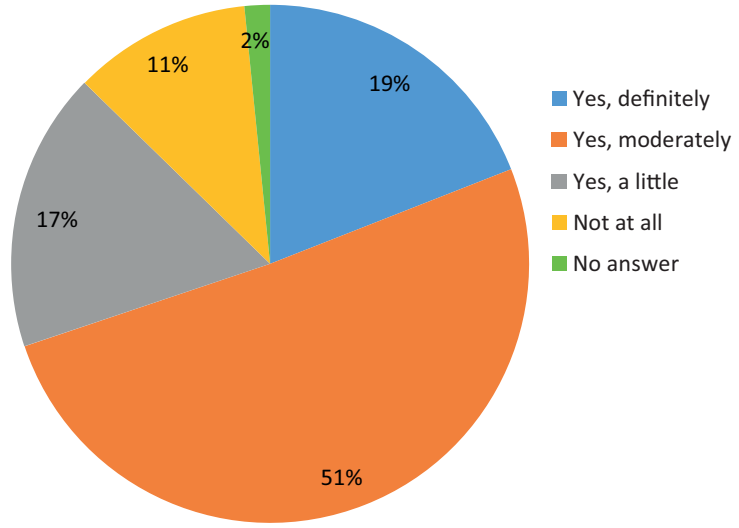

Figure 4 - Answers to the question: Do you think that your socio-economic situation has improved in recent years? $(n=63)$

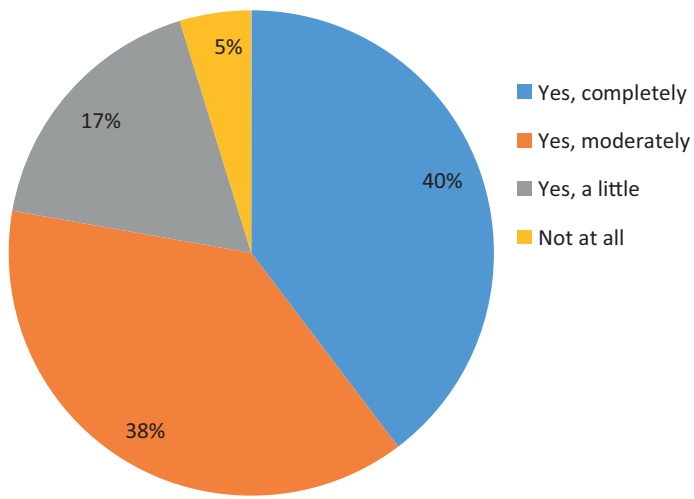

Figure 5 - Answers to the question: Do you think that Huilo Huilo is supporting the local community? $(n=63)$

to Lake Neltume through an 11-kilometre-long tunnel with a diameter of $6.3 \mathrm{~m}$ (Endesa 2016). This would subsequently reduce the water flow of the Fuy River and the runoff of the main attraction, the Huilo Huilo waterfalls, which are already prone to dry out in the summer months.

\section{Feminization of the workforce}

Women especially have benefitted from the economic transition; changes to their working lives have changed the life of the community significantly. When forestry was the main source of employment, most women worked in the home and only a small percentage worked outside, as school teachers, in crafts or in the health sector, for example. The men worked mainly in the forestry industry and were considered the bread-winners. Now, women are able to earn their own money to help their families, mainly in the hotel and restaurant sectors. Many women have been trained in new skills in Huilo Huilo, like baking and cooking. One woman interviewed (40 years old) said: "I have been working in the hotel for four years. Although my income is low, I can help my busband and we can raise our kids. They don't need to work like we did when we were young [...]. Without tourism we would have emigrated, because it is difficult to find a job here in Neltume; maybe in Panguipulli it's easier because it's a small city, but bere... no..." 


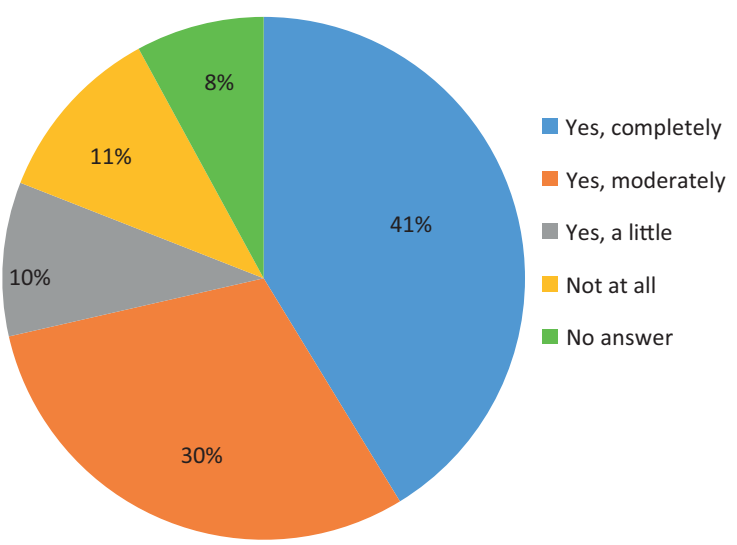

Figure 6-Answers to the question: Do you think that Huilo Huilo supports the community in Neltume? $(n=27)$.

How young people of Neltume see their future

In March 2016, 27 students aged 14 to 16 at the Tierra Esperanza school took part in a survey. (Usually students leave school at 17.) They were asked what career they wanted to follow after school. Eleven replied that they wanted to go to university; 4 replied that they wanted to learn something technical; 4 replied that they wanted to work. Another question concerned whether they would like to work within the Huilo $\mathrm{Hu}-$ ilo project: 5 said that they would like to; 17 said that they would not like to; 5 did not answer the question.

When asked whether they wanted to stay in $\mathrm{Nel}$ tume or leave for a town, 5 declared that they wanted to stay, and 13 that they wanted to leave Neltume for another town in Chile or to leave the country. So the majority of the students wanted to leave the village, as they see a lack of opportunity there. The majority also agreed that Huilo Huilo is a great support for the village. 14 (52\%) out of 27 answered with "Yes, completely" or with "Yes, moderately" (Figure 6). Most claimed that Huilo Huilo gives the community jobs. Neltume and Huilo Huilo do not offer many professional jobs outside the hotel and tourism sector, due to the relative isolation. Most professional Huilo Huilo employees come from other Chilean cities, especially the capital. However, the research also showed that some people from larger cities in Chile move to Neltume and work in tourism or as teachers in the school, because they like the amenities and the pristine surroundings. With increasing economic improvement in the area, some students at Tierra Esperanza might rethink and after completing their education in the cities return to Neltume to work in a local business or within the Huilo Huilo project.

\section{How visitors see the project}

Between October 2014 and October 2015, 12881 Chilean nationals visited Huilo Huilo's hotels, staying at least one night (Fundación Huilo Huilo 2015). Foreign visitors came predominantly from Argentina, Germany, the United States, Brazil and Switzerland (Figure 7). The Reserva Biologica Huilo Huilo is well

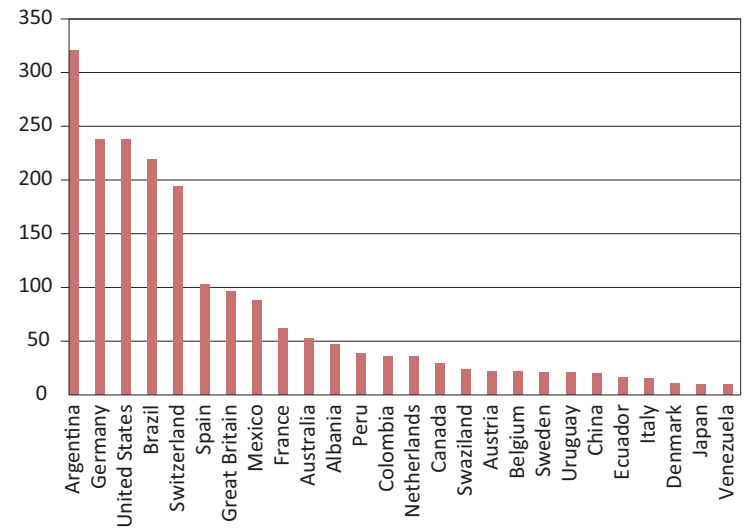

Figure 7 - Foreign visitors to Huilo Huilo hotels, October 2014 to October 2015.

known as an exclusive high-end hotel in the Patagonian rainforest. With the awards gained, international attention was brought to the Huilo Huilo hotels. National and international companies also offer packages and organized tours, which attract more visitors.

Finally, at the entrance to the Huilo Huilo waterfalls, the most-visited attraction in the area, visitors were asked for their opinions about the biological reserve (Figure 8). More than $76 \%$ of the tourists were satisfied with the conservation concept. Most of them had visited the Huilo Huilo waterfalls. The visitors who were not satisfied complained about high prices, of around US $\$ 5$ per person. $60 \%$ of the tourists questioned were staying in holiday flats in Neltume, Puerto Fuy or Choshuenco. 16\% were staying in one of Huilo Huilo's hotels and a further $16 \%$ on nearby campsites. The remaining $10 \%$ were just on a day visit from other cities. Out of the 138 tourists, 19\% were visiting the site as part of a tour organized by an agency, and $71 \%$ were travelling independently, usually by car. $90 \%$ of visitors lived in Chile and 10\% came from abroad. On average, the tourists spend US $\$ 341$ per day. This relatively high amount of money reflects the spending in the high-priced hotels of Huilo Huilo. It is possible, however, that the money spent was for the whole travel group, so the value could be biased.

\section{Concluding remarks}

The economic transformation experienced by Neltume in recent decades has changed the traditional landscape of this mountain area. Nowadays, Neltume and its surroundings are moving away from forestry (extraction of trees) to become an area of specialtourist tourism focused on environmental education and outdoor activities. This rapid change was triggered by a private initiative, which shows the significant role that the private sector can play in regional development in normally marginalized rural areas. In general, the formerly isolated Neltume has seen a sharp increase in connectivity through the development projects triggered by the Reserva Biológica Huilo 


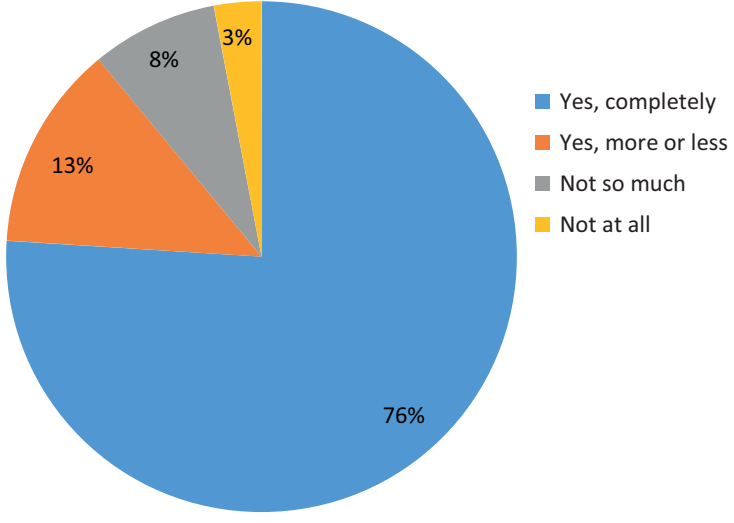

Figure 8-Answers to the question: Do you like the conservation concept of the Reserva Biológica Huilo Huilo? $(n=138)$

Huilo. The Chilean state showed interest in developing the area through infrastructure projects. The northeast shore of the Panguipulli lake now has a paved road, which will be extended to Puerto Fuy in 2017. In the near future, the regional government of the Los Ríos region wants to create a ski resort on the slopes of the Mocho-Choshuenco volcano. This development could combine with the small resort that is already run by Huilo Huilo to make the winter season a significant economic factor.

However, the seasonality of the tourism economy in southern Chile remains a challenge for local communities. This study has shown the need for a more diversified economic base, to reduce the strong dependency on tourism, and especially on Huilo Huilo as the main attraction of the area. On leaving high school, young people tend to move away from the area, as they do not see job opportunities locally.

In contrast, skilled people like teachers and some opportunity-seekers in the tourism sector are arriving in Panguipulli and its surroundings, seeking better environmental living conditions. They could be considered amenity migrants (Moss 2006; Borsdorf et al. 2011), a recent phenomenon already observed both in established mountain tourism destinations in Chile such as Pucón (Zunino \& Hidalgo 2010) and in small mountain villages like Malalcahuello (Marchant \& Rojas 2015). Within the Reserva Biológica Huilo Huilo, some parcels have been sold to allow amenity migrants to construct houses. These are used mainly as second homes by city inhabitants or foreigners. The sale of further parcels is not intended as the area would lose the character of a natural reserve.

The vast majority of the permanent residents of Neltume consider the creation of the PPA a positive development for their village. Most see their economic situation as improving. Furthermore, they appreciate the cultural activities that the Fundacion Huilo Huilo organizes. The future development of the region depends on how the managers of the Reserva Biológica Huilo Huilo, state bodies, the local community and the indigenous community can moderate conflicts of interest (for example, the construction of the planned hydroelectric powerplants). It can be expected that the influx of tourists will increase in the near future. Mitigating the negative side effects, such as increased traffic, and waste and water management, will be an important topic.

\section{Acknowledgements}

This research was supported by the University of Innsbruck through the PhD scholarship NEU Nachwuchsförderung 2015. I am also grateful to the people in Neltume and the Huilo Huilo Foundation, who helped me with data and their valuable local knowledge.

\section{References}

Armesto, J.J., P. León-Lobos \& M.T.K. Arroyo 1996. Los bosques templados del sur de Chile y Argentina: una isla biogeográfica. In: Armesto, J.J., C. Villagrán \& M.T.K. Arroyo (eds.), Ecología de los bosques nativos de Chile, Santiago de Chile. [In Spanish]

Benjaminsen, T.A. \& I. Bryceson, 2012. Conservation, green/blue grabbing and accumulation by dispossession in Tanzania. The Journal of Peasant Studies 39(2): 335-355. Available at: DOI: 10.1080/0306615 0.2012 .667405

Borsdorf, A., R. Hidalgo \& H. Zunino 2011 Amenity migration: a comparative study of the Italian Alps and the Chilean Andes. Journal of Sustainability Education 3. Available at: http://www.jsedimensions. org/wordpress/wp-content/uploads/2012/03/ BorsdorfHidalgoZuninoJSE2012.pdf (accessed: 24/10/16)

Büscher, B. \& W. Whande 2007. Whims in the winds of time: Emerging trends in biodiversity conservation and protected area management. Conservation and Society 5: 22-43.

CODEPU - Corporación de Promoción y Defensa de los Derechos del Pueblo 1990. Chile: Recuerdos de la ,Guerra' Valdivia - Neltume - Chibuio - Liquine. Volumen 2. Santiago de Chile. Available at: http://unidadmpt. wordpress.com/2013/12/07/chile-recuerdos-de-laguerra/ (accessed: 24/10/16) [In Spanish]

Corcuera, E. 2000. Conservación de tierras privadas en Chile y el mundo: ¿Coincidencia o tendencia?. Revista Ambiente y Desarrollo. XVI(4): 36-43. [In Spanish]

Dudley, N. 2008. Guidelines for Applying Protected Area Management Categories. IUCN, Gland, Switzerland.

Echeverría, C., D. Coomes, J. Salas, J.M. Rey-Benayas, A. Lara \& A. Newton 2006. Rapid deforestation and fragmentation of Chilean temperate forests. Biological conservation 130(4): 481-494.

Endesa 2016. Proyecto Central Hidroeléctrica Neltume. Available at: http://www.endesa.cl/es/ conocenos/nuestronegocio/proyectos/Paginas/ CentralNeltume.aspx (accessed: 09/10/16) 
Fairhead, J., M. Leach \& I. Scoones 2012. Green Grabbing: a new appropriation of nature?. The Journal of Peasant Studies 39(2): 237-261. DOI:10.1080/03066 150.2012.671770

Gomez, B. \& J.P. Jones III (eds.) 2010. Research methods in geography: A critical introduction. United Kingdom.

Holmes, G. 2012. Biodiversity for billionaires: capitalism, conservation and the role of philanthropy in saving/selling nature. Development and change 43(1): 185-203. DOI: 10.1111/j.1467-7660.2011.01749.

Holmes, G. 2013. What role do private protected areas have in conserving global biodiversity?. SRI Papers, $\mathrm{N}^{\circ} 46$ Sustainability Research Institute (SRI), School of Earth and Environment, The University of Leeds, United Kingdom.

Holmes, G. 2014. What is a land grab? Exploring green grabs, conservation, and private protected areas in southern Chile. The Journal of Peasant Studies 41(4): 541-567. DOI: 10.1080/03066150.2014.919266

Holmes, G. 2015. Markets, Nature, Neoliberalism, and Conservation through Private Protected Areas in Southern Chile. Environment and Planning A 47(4): 850-866. DOI: 10.1068/a140194p

Igoe, J. \& D. Brockington 2007. Neoliberal conservation: A brief introduction. Conservation and Society 5(4): 432

Kohut, K. 2006. Ein bayerischer Kapuziner bei den Mapuche. In Hoffmann, C., H. Arellano \& R. Kramer Die Mapuche und die Republik Chile: Pater Siegfried von Frauenhäusl und das Parlament der Mapuche von 1907 in Cor Coz: Wiesbaden. [In German]

Marchant, C. \& F. Rojas 2015. Local transformations and new economic functionalities generated by amenity migration in Northern Chilean Patagonia. Revue de géographie alpine 103(3). DOI: 10.4000/rga.2998.

Meza, L. 2009. Mapuche struggles for land and the role of private protected areas in Chile. Journal of Latin American Geography 8: 149-163.

Moss, L. (ed.) 2006. The amenity migrants. Seeking and sustaining mountains and their cultures. CABI, Oxfordshire.

Núñez, M., A. Corcuera, P. Farías, P. Pliscoff, J. Palma, M. Barrientos \& C. Sepúlveda 2013. Diagnóstico y caracterización de las iniciativas de conservación privada en Chile. Fundación Senda Darwin en colaboración con Así Conserva Chile AG para proyecto MMA/GEF PNUD Creación de un sistema nacional integral de áreas protegidas para Chile: estructura financiera y operacional. Santiago de Chile. [In Spanish]

Olsen, W. 2004. Triangulation in social research: qualitative and quantitative methods can really be mixed. Developments in sociology 20: 103-118.

Ojeda, D. 2012. Green pretexts: Ecotourism, neoliberal conservation and land grabbing in Tayrona National Natural Park, Colombia. The Journal of Peasant Studies, 39(2): 357-375. DOI: 10.1080/03066150.2012.658777

Oyarzún, C. \& A. Huber 1999. Balance Hídrico en plantaciones jóvenes de Eucalyptus globulus y Pinus radiata en el sur de Chile. Terra 17(1): 35-44. [In Spanish]
Quintana, J. \& S. Morse 2005. Social interactions and resource ownership in two private protected areas of Paraguay. Journal of Environmental management 77(1): 64 78. Available at: DOI: 10.1016/j.jenvman.2005.02.014

Pegas, F.V. \& J.G. Castley 2014. Ecotourism as a conservation tool and its adoption by private protected areas in Brazil. Journal of Sustainable Tourism 22(4): 604-625. DOI: 10.1080/09669582.2013.875550

Pino, A., D. Cardyn \& Grupo de Trabajo Panguipulli 2014. La Reserva de la Biosfera de los Bosques Templados Lluviosos de los Andes Australes y las singularidades territoriales de la comuna de Panguipulli In: Moreira-Muñoz, A. \& A. Borsdorf (eds.), Reservas de la biosfera de Chile: laboratorios para la sustentabilidad. Academia de Ciencias de Austria, Pontificia Universidad Católica de Chile, Instituto de Geografía, serie Geolibros 17: 190-206. Santiago. [In Spanish]

Pliscoff, P. \& T. Fuentes-Castillo 2011. Modelación de la distribución de especies y ecosistemas en el tiempo y en el espacio: una revisión de las nuevas herramientas y enfoques disponibles. Revista de Geografía Norte Grande 48: 61-79. [In Spanish]

Rivas, R. 2006. Desarrollo Forestal de Neltume: Estado y Trabajadores (1924-1990). Tesis para optar al título de profesor de Historia, Geografía y Educación Cívica, y al grado de Licenciado en Historia. Universidad Austral de Chile, Facultad de Filosofía y Humanidades. Valdivia. [In Spanish]

Román, B. \& L. Nahuelhual 2009. Áreas protegidas públicas y privadas en el sur de Chile. Caracterización del perfil de sus visitantes. Estudios y Perspectivas en Turismo, 18(4) Available at: http://www. scielo.org.ar/scielo.php? script $=$ sci_arttext\&pid =S1851-17322009000400008 (accessed: 26/03/16) [In Spanish]

Sepúlveda, C. 1997. Incentivos para la creación y manejo de Áreas Silvestres Protegidas Privadas en Chile. Ambiente y Desarrollo 13(3): 38-46 [In Spanish]

Sepúlveda, C. \& D. García 1997. Cooperación público-privada como estrategia para la conservación de la biodiversidad en Chile. Ambiente y Desarrollo,13(2): 59-69. [In Spanish]

Serenari, C., N. Peterson, Y. Leung, P. Stowhas, T. Wallace \& E. Sills 2015. Private development-based forest conservation in Patagonia: comparing mental models and revealing cultural truths. Ecology and Society 20(3): 4. DOI: 10.5751/ES-07696-200304

Sierralta, L., R. Serrano, J. Rovira \& C. Cortés (eds.) 2011. Las áreas protegidas de Chile, Ministerio del Medio Ambiente, Santiago. [In Spanish]

Tecklin, D. \& C. Sepúlveda 2014. The diverse properties of private land conservation in Chile: growth and barriers to private protected areas in a marketfriendly context. Conservation \& Society 12(2): 203-217. DOI: $10.4103 / 0972-4923.138422$

Wilson, K., A. Newton, C. Echeverria, C. Weston \& M. Burgman 2005. A vulnerability analysis of the temperate forests of south central Chile. Biological Conservation 122(1): 9-21. 
Zumelzu, L. 2014. Neltume, de una economía maderera a enclave del turismo de conservación: Una aproximación a las transformaciones económicas y socio-ambientales 1990- 2010. Seminario de título para optar al título de Profesora de Historia y Ciencias Sociales y a los grados de Licenciada en Educación-Bachiller en Humanidades y Ciencias Sociales, Universidad Austral de Chile, Valdivia. [In Spanish]

Zunino, H.M. \& R. Hidalgo 2010. En busca de la utopía verde: migrantes de amenidad en la comuna de Pucón, IX región de La Araucanía, Chile. Scripta Nova Revista Electrónica de Geografía y Ciencias Sociales, XIV(331). Available at: http://www.ub.edu/geocrit/ sn/sn-331/sn-331-75.htm (accessed: 20/10/16) [In Spanish]

\section{Author}

\section{Benedikt Hora}

studied Geography at the University of Innsbruck, Austria, and gained a Master's degree in Global Change and Regional Development from the same university. $\mathrm{He}$ is currently a $\mathrm{PhD}$ student at the University of Innsbruck. His research interests are mountain science, regional development, settlement geography and the geography of rural areas. His focus regions are Latin America and Europe.

Institute of Geography, University of Innsbruck, Innrain 52f; 6020 Innsbruck, Austria, E-mail: benedikt. hora@student.uibk.ac.at 